УДК 323.2

https://doi.org/10.34142/24130060.2019.18.2.07

\title{
«ВИБУХ ПОПУЛІЗМУ» У ХХІ СТОЛІТТІ: ДОСЛІДНИЦЬКІ ІНТЕНЦЇ̈ ЩОДО ВИЗНАЧЕННЯ «УНІВЕРСАЛЬНИХ» ХАРАКТЕРИСТИК
}

\author{
А.О. Житко \\ Харківський національний педагогічний університет імені Г.С. Сковороди
}

Спираючись на новітні західні та вітчизняні теоретичні конструкції автор статті пропонуе власну дефініцію «сучасного популізму» - як політичного поліваріативного феномену, який в залежності від унікальної комбінації специчфічних рис, може виступати в якості ідеології, методу політичної боротьби, суспільно-політичного руху, маніпулятивної технологї̈, стилю політичної поведінки тощо. В ракурсі визначеної дослідницької позииії автор робить спробу визначити «універсальні» характеристики феномену «сучасний популізм» - «акумулячія незадоволення», «гра на емочіях», «народовладдя», «політика симулякрів», «начіональна автентичність», а також охарактеризувати специфічні рис «сучасного украӥнського популізму». Акцентовано увагу на тому, ще «сучасний популізм» становить реальну загрозу для загальновизнаної ліберально-демократичної світоглядної позичії сучасної ичивілізачії, відтак, автор статті спрямовує дослідниці інтениії на пошук ефективних стратегій протидії даному феномену.

Ключові слова: популізм, сучасний популізм, «універсальні» характеристики феномену «сучасний популізм», «сучасний український популізм», ліберальнодемократичні цінності, демократичні ризики,стратегії протидї.

\section{«ВЗРЫВ ПОПУЛИЗМА» В ХХІ ВЕКЕ: ИССЛЕДОВАТЕЛЬСКИЕ ИНТЕНЦИИ ОТНОСИТЕЛЬНО ОПРЕДЕЛЕНИЯ «УНИВЕРСАЛЬНЫХ» ХАРАКТЕРИСТИК}

\begin{abstract}
А.А. Житко
Опираясь на новейшие западные и украинские теоретические конструкиии автор статьи предлагает собственную дефиницию «современного популизма» -как политического поливариативного феномена, который в зависимости от уникальной комбинации специфических черт, может выступать в качестве идеологии, метода политической борьбы, общественно-политического движения, стиля политического поведения и т.д. В ракурсе обозначенной исследовательской позиции автор делает попытку определить «универсальные» характеристики феномена «современный популизм» - «аккумулящия недовольства», «игра на эмочиях», «народовластие», «политика симулякров», «национальная аутентичность», а также охарактеризовать специффические черты «современного украинского популизма». Внимание акцентировано на том, что современный популизм представляет реальную угрозу для общепринятой либерально-демократической мировоззренческой позичии современной ичивилизачии, следовательно, автор статьи направляет исследовательские интенции на поиск эффективных стратегий противодействия данному феномену.
\end{abstract}

(C) А.О. Житко, 2019 
Ключевые слова: популизм, современный популизм, «универсальные» характеристики феномена «современный популизм», «современный украинский популизм», либерально-демократические ценности, демократические риски, стратегии противодействия.

\section{THE POPULISM EXPLOSION IN THE XXI CENTURY: RESEARCH INTENTIONS TO DEFINE «UNIVERSAL» CHARACTERISTICS}

\section{A. Zhitko}

Being based on the latest Western and domestic theoretical constructs, the author offers his own definition of «modern populism» as a political multivariate phenomenon, which, depending on the unique combination of specific features, can act as an ideology, method of political struggle, sociopolitical technology, manipulative technology, manipulative technology style of political behavior and more. Within the framework of a definite research position, the author attempts to define the «universal» characteristics of the phenomenon of «modern populism» as «accumulation of discontent», "play on emotions», «democracy», "politics of simulacra», "national authenticity», as well as to characterize specific features "of modern Ukrainian populism». Firstly, the Ukrainian society has been in a state of «excessive emotional socio-political tension» for a long time, in the minds of «ordinary Ukrainians» «despair», «disappointment», «confusion» and so are dominating, therefore, the constant «generation and accumulation of discontent» with power pose «nourishing ground» for the «heyday» of modern Ukrainian populism; secondly, it is the unfinished transformation of political culture in the minds of many Ukrainians, there is no clear understanding of the issues of authority, interaction and responsibility between government institutions and citizens. The «blurred outlines» of fundamental liberal-democratic values, the inherent «contempt and conflict», all this creates favorable conditions for manipulating of the socio-political sentiments of Ukrainians (from apathy to revolutionary uplift), which is what populist politicians use.

Attention is drawn to the fact that «modern populism» poses a real threat to the universally recognized liberal-democratic worldview of modern civilization; therefore, the appeal to the modern scientific community is justified by the fact that research intentions, in order to understand the phenomenon of modernism, should not cover theoretical plane only explication of the concept such as theoretical and methodological constructions of knowledge of nature and essence, attempts to determine specific features and typologization, etc., but also the practical plane, in particular - by looking for effective counteraction strategies.

Key words: populism, modern populism, «universal» characteristics of the phenomenon «modern populism», «modern Ukrainian populism», liberal and democratic values, democratic risks, counter action strategies.

Постановка проблеми. «Вибух популізму» у XXI столітті становить реальну загрозу для загальновизнаної ліберально-демократичної світоглядної позиції сучасної цивілізації - «сучасний популізм став реальною загрозою для ліберальних демократій через зменшення терпимості, зневаги до опозиції, нехтування свободою слова, підриві офіційних інститутів демократії, знеціненні неформальних цінностей, які покладено в основу демократі» (Гржимала-Бюссе, 2018); «популізм став означенням 
новостворених політичних чи громадських рухів, які виступають проти визнаних цінностей, принципів та ортодоксальних демократичних інститутів» (Прядко, 2017, с. 49).

Чи становить «сучасний популізм» загрозу для процесів демократичного державотворення сучасної України?, адже за песимістичною заявою провідного філософа сучасності Бернар-Анрі Леві «...популісти є серйозною небезпекою для $\mathrm{CC}$, але вони набагато небезпечніші для вас, українців... Для України популізм - небезпека смертельна» (Духнич, 2019). Відтак, дослідницькі інтенції науковців сучасності, щодо феномену «сучасного популізму», повинні охоплювати не лише теоретичну площину експлікація поняття, теоретико-методологічні конструкції пізнання природи та сутності,спроби визначення специфічних рис і типологізації тощо, а й практичну площину, зокрема, - пошук ефективних стратегії протидії.

Аналіз актуальних досліджень. Фундаментальні теоретикометодологічні розвідки у пізнанні природи та сутності феномену «популізм», відбулись наприкінці XX - початку XXI століття, завдяки роботам Г. Іонеска та Е.Гелнера «Популізм: його значення i національні характеристики» (1969), Д. Белла «Популізм і елітизм: політика в епоху рівності» (1992), М. Кенована «Популізм» (1981), П. Таггарта «Популізм» (2000), Е. Лаклау «Причини популізму» (2005), Ф. Паніцци «Популізм і дзеркало демократії» (2005), I. Мені та І. Сорель «Демократія під призмою популізму» (2007) та інші.

Проблемне поле феномену «сучасний популізм» перебуває у фокусі дослідницької рефлексії провідних експертів сучасної гуманітаристики 3. Баумана, У. Бека, Б. Бекера, К. Вейланда, Ф. Вентурі, К. Верніке, Дж. Гарсія, М. Годвіна, А. Гржимала-Бюссе, К. Дейвікст, Дж. Джудіса, У. Еко, Б. Еммотта, Д. Зіблатт, Р. Ітвелла, М. Казіна, Дж. Кейтеба, Р. Кеннета, Е. Колба, Е. Крейг, М. Круза, С. Левіцкі, К. Мадде, Д. Макре, Я.-В. Мюллера, Е. Папареллі, Д. Родріка, С. Сабала, Т. Снайдера, Х. Торребланка, А. Турена, Ф. Фукуями, Р. Хофстартера, Р. Хурадо та багатьох інших. 
Розгорнутий дискурс і багатий теоретичний зміст, щодо проблематики феномену «сучасного популізму», презентовано й в роботах вітчизняних дослідників - Т. Андрущенко, О. Бабкіної, В.Бебика, С. Бульбенюк, К. Ващенка, Д. Видріна, Д. Гаврилюка, М. Головатого, І. Горбатенко, С. Дацюк, М. Дем’яненка, С. Денисюк, О. Дубини, І. Кіянки, В. Корнієнка, В. Кривошеїна, Г. Куц, Н. Латигіної, О. Ліснічук, Л. Матлай, С. Мигаль, О. Новакової, М. Остапенко, І. Побочия, А. Погорєлової, В. Полторака, Т. Прядко, Т. Радь, Н. Рєзанової, О. Стогової, О. Яроша та інших.

Виходячи з вище зазначеного, мета статті - в рамках новітніх західних i вітчизняних теоретичних конструкцій визначити та проаналізувати «універсальні» риси «сучасного популізму», охарактеризувати специфічні риси «сучасного українського популізму» та здійснити спроби пошуку ефективних стратегій протидії «сучасному популізму».

Виклад основного матеріалу. На складність та багатогранність феномену «популізм» вказує широкий спектр дефініцій презентованих в сучасному політологічному просторі. Так, в міркуваннях провідних західних дослідників популізм - це «рух, який апелює до «народу», протиставляючи себе в рівній мірі існуючим структурам влади та домінуючим у суспільстві ідеям і суспільним цінностям» (Canovan, 1999, p. 3); «неповна, незавершена ідеологічна течія та метод, згідно з якою «народ» представляється як певне органічне ціле та носій певної правоти та моральності, джерело влади, яку він має собі «повернути». 3 «народу» при цьому виключаються певні групи, що представляються як «ворожі»: еліти, іммігранти, інтелектуали тощо (Дейвикс, ); «ідеологія, що вважає суспільство кардинально поділеним на дві гомогенні та антагоністичні групи - «простий народ» та «корумповану еліту», і стверджує, що політика має виражати єдину волю народу» (Ганспетер, 2018).

В інтерпретаціях вітчизняних дослідників «популізм» розуміється, як: «визначення нераціональної політики ігнорування об’єктивних тенденцій суспільного розвитку та спекуляції на емоціях громадян з метою досягнення 
власної мети й перемоги над опонентами (Новакова, 2017, с. 140); «маніпулятивна технологія, що застосовується в процесі комунікації з метою впливу на свідомість громадян, для досягнення бажаних результатів у боротьбі за владу та в процесі іiі здійснення», i уточнює «віднесення популізму до некоректних технологій пояснюється тим, що він проявляє себе як сукупність протизаконних чи етично сумнівних засобів, способів, прийомів організації і проведення кампаній, спрямованих на створення переваги над суперниками» (Дем’яненко, 2015, с.150); «явище дисперсне, тобто воно $є$ складовою багатьох політичних феноменів, утілюється в різноманітні ідеологічні форми та політичні стратегії» (Ярош, 2002, с. 22).

Спираючись на теоретичний плюралізм сучасних західних та українських дослідників, запропонуємо власне визначення: «сучасний популізм - це політичний поліваріативний феномен, який в залежності від унікальної комбінації специфічних рис, може виступати в якості ідеології, методу політичної боротьби, суспільно-політичного руху, маніпулятивної технології, стилю політичної поведінки тощо, відтак, на нашу думку, найбільш доцільним і обгрунтованим, для розуміння феномену «сучасного популізму» є визначення його специфічних рис і характеристик.

У сучасному політологічному дискурсі, завдяки масштабній дослідницькій роботі західних і вітчизняних науковців, представлено різноманітні варіації, щодо визначення специфічних рис і характеристик феномену популізм. Так, на беззаперечно компліментарну оцінку заслуговує теоретична конструкція британського «класика» П. Таггарта, який визначив ключові ознаки популізму наступним чином: 1) негативне сприйняття представницької політики; 2) часте звертання до ідеалізованої «середини», в якому все: суспільство, політика, економіка - відображає цінності й вірування «звичайних» людей; 3) «нестача основних цінностей»; 4) популістський рух зазвичай активізується під час криз, тобто тоді, коли соціальні, економічні й політичні структури знаходяться в складному становищі; 5) популістські рухи недовготривалі, тобто вони втрачають своє 
«обличчя», як тільки стають частиною тих структур, проти яких вони так рішуче виступали; 6) природа популізму залежить від національного контексту, в якому проявляється популізм (Taggart, 2000).

Провідний український експерт 3 проблематики популізму Т. Радь, пропонує значно ширший спектр основних ознак i специфічних рис: «1) попри те, що популізм $є$ інтелектуальним продуктом, по суті він залишається анти інтелектуальним; популізм ідеалізує маси і протиставляє їх еліті; 2) формально популізм засновується на демократичних засадах, в той час як в дійсності він не є і не може таким бути; 3) популізм постійно апелює до «золотого віку», який виступає ідеалізованим образом кращого минулого; 4) популізм дає власне й інше трактування минулого i майбутнього; 5) популізм пропонує «третій шлях» суспільного розвитку, який поєднує найкраще з існуючого і власні погляди; 6) популізму властива націоналізація державної власності і вороже ставлення до іноземного капіталу; 7) абсолютизація народних цінностей, культури і звичаїв; 8) ірраціональна природа популізму: апеляція до почуттів та емоцій маси; 9) популізм надає перевагу рухам (i в переважній більшості зароджується в них) перед політичними партіями, опираючись на широку соціальну базу (Радь, 2010, с. 25). У відповідності до міркувань вітчизняного політолога Ю. Калюжної, домінантними рисами «сучасного популізму» $\epsilon$ : «агресивна експансія» (комплекс специфічних характеристик: масштабність, турбулентність, динамізм, радикалізація тощо), «парадоксальність» - (представницька демократія є базовою детермінантою сучасного популізму), «багатоликість» - Д. Трамп (США), Г. Вілдерс (Нідерланди), А. Фухіморі (Перу), В. Орбан (Угорщина), П. Генсон (Австралія), Р. Ердоган (Туреччина), Р. Корреа (Еквадор), Й. Хайдер (Австрія), Р. Мугабе (Зімбабве), «Рух П’ять Зірок» (Італія), «Подемос» (Испанія) та ін.» (Калюжна, 2017, с. 81).

Акцентуємо, в представлених теоретичних конструкціях сучасних дослідників, простежуються певна «універсальність» характеристик 
феномену «сучасний популізм», отже, спробуємо їх окреслити виходячи 3 власної дослідницької позиції:

- «акумуляція незадоволення» - влада що нездатна ефективно відповідати на запити та вимоги суспільства, 3 часом втрачає свою легітимність, адже ігнорування суспільних потреб призводить до накопичення негативу відносно існуючих владних інституцій, відтак, громадянське незадоволення стає джерелом «потужної політичної енергії» для політиків - популістів;

- «гра на емоціях» - політики-популісти використовують «кризовий стан» держави/суспільства, спекулюючи на «соціально гострих» темах (війна, тероризм, безробіття, мігранти, злочинність, екологія тощо), апелюючи до ірраціональних емоцій виборців - розгубленість, розчарування, страх, гнів та інше;

- «народовладдя» - «звичайна людина», «пересічний громадянин», «народ»є головним інструментом політиків-популістів в боротьбі за владу, маніпулюючи суспільно-політичними настроями вони звинувачують «старі» еліти в надмірній елітарності, корумпованості, заангажованості, бездіяльності, тобто відновлення «народовладдя» становить основу політичної платформи сучасних популістів;

- «nолітика симулякрів» - політики-популісти «грають» 3 виборцями пропонуючи «прості рішення складних проблем», обіцяючи різні пільги, нові робочі місця, вирішення проблем 3 мігрантами чи екологією та інші демагогічні гасла, які не мають «реального політичного і економічного підгрунтя» для реалізації, а відтак не будуть в майбутньому виконані;

- «національна автентичність» - популізм завжди має певну «національну специфіку», кожна держава має власну історію, соціальноекономічні показники, рівень політичної культури, соціальні групи, що «акумулюють незадоволення» - це може бути «середній клас», безробітні, мігранти, екоактивісти, фермери та ін.; - тобто комплекс унікальних рис, що визначають природу та специфіку сучасного популізму в тій чи іншій країні. 
Щодо перспектив наблизитись до розуміння природи та специфіки «сучасного українського популізму», то на нашу думку, доцільним видається залучення вищезазначених «універсальних» характеристик - «акумуляція незадоволення», «гра на емоціях», «народовладдя», «політика сімулякрів», «національна автентичність», повний комплекс яких відображається в політичному просторі сучасної України. Здійснюючи аналіз «національної автентичності» сучасного українського популізму можна визначити специфічні риси даного феномена:

по-перше, складний процес сучасного українського державотворення пов’язаний з досвідом «Помаранчевої Революції» та «Революції Гідності», військово-політичного конфлікту з РФ, «системних криз» в політичному та соціально-економічному секторах тощо - змушує українське суспільство постійно перебувати у стані «надмірної емоцуінальної соцуіально-політичної напруги»; в українському суспільстві, що постійно «генерує та акумулює незадоволення» домінують - «зневіра», «розчарування», «розгубленість» та інші ірраціональні емоції, що стають «поживним підгрунтям» для «розквіту» сучасного українського популізму;

по-друге, незавершена трансформація політичної культури - у свідомості багатьох українців немає чіткого розуміння щодо питань повноважень, взаємодії та відповідальності між владними інституціями та громадянами, «розмиті контури» фундаментальних ліберальнодемократичних цінностей, притаманна «зневага та конфліктогенність» до політичних опонентів тощо, - все це створює сприятливі умови для маніпулювання суспільно-політичними настроями українців - від апатії до революційного піднесення - чим й користуються політики-популісти.

Базовим інструментом у протидії «сучасному популізму» є стратегія ефективної державної політики заснована на: 1) взаємозворотньому зв’язку між політичними інститутами та громадянами, здатними своєчасно реагувати на запити та вимоги суспільства; 2) консолідованій платформі та чітко скоординованих діях щодо політичного майбутнього країни; 3) розробці та 
імплементації масштабних освітніх проектів, 3 громадянської освіти, медіаграмотності, праймінга та ін.

Висновки та перспективи подальших досліджень. Зауважимо, популізм є невід’ємною складовою сучасного політичного процесу, i в «помірних дозах» може виконувати навіть позитивну функцію: «Конструктивний популізм оперує цифрами, фактами, аргументами, висловлює не персональні претензії, а намагається розібратися в суті проблем. Він не тільки критикує, а й надає конкретні пропозиції, які навіть в своїй зорієнтованій на популярність формі мають стратегічний характер» (Дацюк, 2016). Проте, в політичному просторі сучасної України переважає «деструктивний популізм», який «паразитує» на наявних політичних та соціально-економічних кризах, і не лише не здатен їх вирішити, а й продукує нові, поступово утворюючи «критичну масу», що в свою чергу стає реальною загрозою для ліберально-демократичного майбутнього України. Виходячи 3 вищевикладеного, можна обгрунтовано припустити, що пошук ефективних стратегій протидії «сучасному популізму», належить до пріоритетних напрямів розвитку сучасного політологічного знання.

\section{ЛІТЕРАТУРА}

1. Гржимала-Бюссе, А., 2018. Чому популізм перемагає в Україні та світі. Інтерв'ю з професором політології Стефорда. [online] Доступно: https://nv.ua/ukr/world/populizm-peremahaje-tomu-shcho-vibortsjam-ostohidli-partiji-tajikh-lideri-jaki-do-nikh-ne-doslukhajutsja-intervju-z-profesorom-politolohiji-stenforda2454303.html [Дата звернення 27 січня 2019].

2. Дацюк, С., 2016. Чи загрожує Україні популізм? [online] Доступно: https://blogs.pravda.com.ua/authors/datsuk/57c91f20023c9/ [Дата звернення 4 березня 2019].

3. Дейвикс, К., 2012. Популизм. [online] Доступно: http://gefter.ru/archive/6800 [Дата звернення 4 лютого 2019].

4. Дем'яненко, М. М., 2015. Популізм як політичний феномен $і$ маніпулятивна технологія. Кандидат наук. Дисертація. Київський національний торговельноекономічний ун-т.

5. Духнич, О., 2019. О чем говорят в Париже. [online] Доступно: https://magazine.nv.ua/journal/3340-journal-no-06/o-chem-hovorjat-vparizhe.html [Дата звернення 1 березня 2019]. 
6. Калюжна, Ю. І., 2017. Популізм, як політико-культурний феномен сучасної світової політики. Сучасне суспільство: політичні науки, сочіологічні науки, культурологічні науки, 2(14), с. 80-87.

7. Крізі, Г., 2018. Випробування популізмом: у чому особливість ситуації у Східній Свропі [online] (Останнє оновлення 30 березень 2018). Доступно: https://voxukraine.org/uk/viprobuvannya-populizmom-u-chomu-osoblivist-situatsiyi-ushidnij-yevropi/ [Дата звернення 9 лютого 2019].

8. Новакова, О.В., 2017. Тренд популізму у сучасному політичному процесі. Вісник Дніпропетровського університету. Серія Філософія, Соціологія, Політологія : збірник наукових праць, 1(35), с. 137-145.

9. Прядко, Т.П., 2017. Популізм як ризик демократичного розвитку $і$ засіб політичної мобілізації електорату. Кандидат наук. Дисертація. Національний педагогічний університет імені М.П. Драгоманова. [online]. Доступно: https://npu.edu.ua/images/file/vidil_aspirant/dicer/D_26.053.12/dis_Priadko.pdf [Дата звернення 2 березня 2019].

10. Радь, Т., 2010. Методологічні засади дослідження популізму як соціального політичного явища. Методологія політичної науки: матеріали Всеукраӥнської наукової конферениіі. Перші методологічні читання. [online] Доступно: http://old.filos.lnu.edu.ua/metod_polit_nauky_tezy.pdf [Дата звернення 11 лютого 2019].

11. Ярош, О., 2002. Політичний популізм: теорія і практика передвиборного «флірту». Контекст, 2, с. 21-25.

12. Canovan, M., 1999. Trustthe People! Populism and the Two Facesof Democracy. Political Studies, [online] 47(1), pp. 3-12. Available at: https://onlinelibrary.wiley.com/doi/abs/10.1111/1467-9248.00184 [Accessed 23 January 2019].

13. Taggart, P. 2000. Populism. Buckingham PA: Open University Press.

\section{Інформація про автора}

Житко Андрій Олександрович - аспірант кафедри політології, соціології і культурології Харківського національного педагогічного університету імені Г.С. Сковороди; e-mail: zhytkoscience.2019@gmail.com; ORCID: https://orcid.org/0000-0002-7003-5562

Стаття надійшла до редакції: 13.03.2019 р. $\quad$ Прийнята до друку: 25.03.2019 p. 